\title{
Eläinaineksen vaikutus porsaiden tuotanto-ominaisuuksiin
}

\author{
Liisa Voutila ${ }^{1)}$, Kirsi Partanen ${ }^{1)}$, Marja-Liisa Sevón-Aimonen ${ }^{2)}$ ja Hilkka Siljander-Rasi ${ }^{1)}$ \\ ${ }^{1)}$ MTT Kotieläintuotannon tutkimus, Tervamäentie 179,05840 Hyvinkää, liisa.voutila@,mtt.fi \\ 2) MTT Biotekniikka- ja elintarviketutkimus, H-talo, 31600 Jokioinen
}

\section{Tiivistelmä}

Rotuja vertailevien tutkimusten puutteiden vuoksi ei ole selvää käsitystä siitä, mikä käytettävissä olevista rotuyhdistelmistä on koko tuotantoketjun kannalta taloudellisesti järkevin. Rotuja vertailtaessa on tarkasteltava niiden eroja koko tuotantoketjussa, ei vain yksittäisiä ominaisuuksia jossain tuotantovaiheessa. Tässä raportoidut porsaiden tuotantotulokset ovat tutkimuksesta, jossa selvitetään lihantuotanto-ominaisuuksien sekä lihan laadun taloudellinen arvo koko tuotantoketjun kannalta sekä kokonaisuuden kannalta kustannustehokkain risteytysohjelma.

Kokeeseen tuotettiin yhteensä 81 pahnuetta (kaikkiaan 945 porsasta). Koeporsaat tuotettiin kotimaisten maatiais- ja yorkshirerotujen risteytysensikoilla. Isinä olivat suomenmaatiais-, norjanmaatiais-, norjanduroc x maatiais- ja ruotsinhampshirekarjut (M, NM, DM ja H). Siemennyksiin käytettiin yksilökarjujen spermaa ja isinä mahdollisimman monta eri karjua. Ensimmäiset pahnueet tuotettiin siten, että kutakin roturyhmää kohti siemennettiin kuusi ensikkoa. Seuraavissa pahnueissa käytettävä isärotu oli aina eri rotu kuin aikaisemmin tuotettujen pahnueiden rotu, jolloin emäaineksen vaikutus tuloksiin saatiin minimoiduksi.

Tiineysaikana annettiin tiineysrehua $2,4 \mathrm{ry} / \mathrm{pv} 1$. tiineydessä ja 2 . ja 3. tiineydessä samaa rehua kuntoluokan edellyttämät annokset. Imetysaikana annettiin rehua $2,5 \mathrm{ry} / \mathrm{pv}$ emakon ylläpitoon ja 0,6 ry/pv/porsas. Syntymä- ja vieroituspainot punnittiin. Porsaskuolemat merkittiin pahnuekortille. Joitakin pahnueita jouduttiin tasaamaan, tasaus tehtiin vuorokauden sisällä syntymästä. Heikoille ja pienille porsaille annettiin tarvittaessa syntymän jälkeen elvytysvalmistetta. Vieroitusikä oli keskimäärin 28 päivää.

Värillisillä roduilla $(\mathrm{DM}, \mathrm{H})$ siemennetyille emakoille syntyi hieman enemmän porsaita (yhteensä ja elävänä) kuin maatiaisroduilla (M, NM) siemennetyille emakoille. Vieroitusvaiheessa NM-porsaita oli vähiten pahnuetta kohti, mutta niiden vieroituspaino oli suurin. Tämä heijastui myös pahnuepainoon vieroitettaessa, joka oli suurin NM-porsailla. Porsaiden kuolleisuus M-pahnueissa oli suurin syntyessä, mutta pienin syntymän ja vieroituksen välillä. Tästä ilmeisesti johtui, että vieroitettujen porsaiden lukumäärässä vain NM-pahnueet erottuivat joukosta. Porsaiden kokonaiskuolleisuus syntymän ja vieroituksen välillä oli pienin M-pahnueissa ja suurin DMpahnueissa. Tämän tutkimuksen aineisto oli kuitenkin niin pieni, että pahnuetasolla isärotujen välisten erojen testaaminen tilastollisesti ei ollut mielekästä. Porsaiden päiväkasvu pahnueaikana oli 283-298 g/pv. H-porsaat kasvoivat hitaimmin ja NM-porsaat nopeimmin, mutta erot eivät olleet tilastollisesti merkitseviä. Tuotannollis-taloudellisesti edullisimman isärotuvaihtoehdon määrittämiseksi on analysoitava porsaiden koko elinkaaren tuotantotulokset.

\section{Asiasanat}

porsas, tuotanto, rotu, risteytys 


\section{Johdanto}

Risteyttämisen tiedetään parantavan porsaiden elinvoimaa ja päiväkasvua (Johnson ym. 1978, Pietola 2002). Risteytysporsaita tuottamalla pystytään siis laskemaan porsaan tuotantokustannusta. Sikojen rotuja vertailevien tutkimusten puutteiden vuoksi ei ole selvää käsitystä siitä, mikä käytettävissä olevista rotuyhdistelmistä on koko tuotantoketjun kannalta taloudellisesti järkevin. Rotuja vertailtaessa on tarkasteltava niiden eroja koko tuotantoketjussa, ei vain yksittäisiä ominaisuuksia jossain tuotantovaiheessa. Suomalaisessa sianjalostuksessa on tuotu esille, että verrattuna kahden rodun käyttöön kolmiroturisteytyksiä käytettäessä elävänä syntyneiden ja vieroitettujen porsaiden lukumäärä kasvaa, mikä laskee porsaan tuotantokustannusta (Rauhala 2008). Lisäksi Muhosen (2004) mukaan pahnuekoon kasvu yhdellä porsaalla on taloudellisempaa, jos se saavutetaan vähentämällä porsaskuolleisuutta porsimisen ja vieroituksen välillä, kuin jos se saadaan aikaan elävänä syntyneiden porsaiden lukumäärän kasvattamisella.

Painotuseroista johtuen suomalaisten sikatalousyrittäjien etu on, että rotujen väliset erot tutkitaan. Jotta kokonaisuudesta saadaan luotettava kuva, pitää tuntea eri ominaisuuksien väliset yhteydet. Aiempien tutkimusten mukaan hedelmällisyys ja tuotanto-ominaisuudet (kasvu, rehunhyötysuhde, ruhon laatu, lihan laatu) eivät ole toisistaan riippumattomia (Serenius ym. 2004). Tässä esityksessä tarkastellaan ensimmäisiä neljän eri isärodun porsastuotantotuloksia tutkimuksesta, jossa selvitetään lihantuotanto-ominaisuuksien sekä lihan laadun taloudellinen arvo koko tuotantoketjun kannalta sekä kokonaisuuden kannalta kustannustehokkain risteytysohjelma. Muita kasvatusvaiheita koskevat tulokset valmistuvat myöhemmin.

\section{Aineisto ja menetelmät}

Kaikki kokeen pahnueet kasvatettiin MTT Kotieläintuotannon tutkimuksen yhdistelmäsikalassa Hyvinkäällä. Ensimmäinen siemennys koetta varten tehtiin toukokuussa 2007 ja viimeinen joulukuussa 2008. Viimeinen kokeen pahnue vieroitettiin toukokuussa 2009. Koeporsaat tuotettiin kotimaisten maatiais- ja yorkshirerotujen risteytysensikoilla ja emakoilla. Isinä olivat suomenmaatiais-, norjanmaatiais-, norjanduroc x norjanmaatiais- ja ruotsinhampshirekarjut (M, NM, $\mathrm{DM}$ ja H). Siemennyksiin käytettiin yksilökarjujen spermaa. Suomenmaatiaiskarjujen sperma tuli FABA Sika Oy:ltä, ja muihin roturyhmiin karjunsperma tuli Finnpig Oy:ltä. Isinä käytettiin mahdollisimman monta eri karjua.

Kokeen nopeuttamiseksi suunniteltiin ostettavaksi 24 ensikkoa, mutta tiinehtymisongelmista johtuen ostoensikoiden määrä jäi yhdeksään. Ostoensikoiden ryhmää täydennettiin MTT:n omilla ensikoilla. Ostoensikoiden ryhmää seurattiin kolmen pahnueen ajan. Ensimmäiset pahnueet tuotettiin siten, että kutakin roturyhmää kohti siemennettiin kuusi ensikkoa. Toisia pahnueita varten tavoitteena oli siementää 5 ja kolmansia pahnueita varten 4 emakkoa kuhunkin roturyhmään. Seuraavissa pahnueissa käytettävä isärotu oli aina eri rotu kuin aikaisemmin tuotettujen pahnueiden rotu, jolloin emäaineksen vaikutus tuloksiin saatiin minimoitua. Ostoensikoiden ryhmässä tuotettiin jokaista roturyhmää kohti yhteensä 11-13 pahnuetta. Loput pahnueet tuotettiin MTT:n omilla maatiaisyorkshireristeytys-emakoilla, jotka olivat porsineet enintään kaksi kertaa ennen tätä koetta. Toteutunut karjujen käyttö ja syntyneiden pahnueiden määrä eri porsimakerroilla on esitetty taulukossa 1.

Taulukko 1. Karjujen käyttö roturyhmittäin.

\begin{tabular}{lcccc}
\hline Isäkarjun rotu & $\begin{array}{c}\text { Suomen- } \\
\text { maatiainen }\end{array}$ & Norjanmaatiainen & $\begin{array}{c}\text { Norjanduroc } \mathrm{x} \\
\text { norjanmaatiainen }\end{array}$ & Ruotsinhampshire \\
\hline Eri isäkarjuja, kpl & 17 & 16 & 17 & 16 \\
1 pahnue/karju & 14 & 12 & 15 & 12 \\
2 pahnuetta/karju & 2 & 4 & 2 & 4 \\
3 pahnuetta/karju & 1 & - & 1 & - \\
Pahnueita yhteensä & 21 & 20 & 20 & 20 \\
1. porsimakerta & 10 & 7 & 8 & 10 \\
2. porsimakerta & 4 & 6 & 8 & 1 \\
3. porsimakerta & 7 & 7 & 4 & \\
\hline
\end{tabular}

Tiineysaikana annettiin tiineysrehua $2,4 \mathrm{ry} / \mathrm{pv}$ 1. tiineydessä ja 2. ja 3. tiineydessä samaa rehua kuntoluokan edellyttämät annokset. Imetysaikana annettiin rehua 2,5 ry/pv emakon ylläpitoon ja 0,6 
ry/pv/porsas. Syntymä- ja vieroituspainot punnittiin. Porsaskuolemat kirjattiin. Kuudesta koepahnueesta jouduttiin siirtämään porsaita toiselle emakolle ja kuuteen koepahnueeseen siirrettiin porsaita toisesta pahnueesta. Pahnueiden tasaus tehtiin vuorokauden kuluessa syntymästä ja niissä ei huomioitu rotu- tai koerajoja. Tuloksissa porsaiden kaikki tiedot on yhdistetty niiden synnyttäjään, koska kaikki imettäjät eivät olleet tässä kokeessa. Heikoille ja pienille porsaille annettiin tarvittaessa syntymän jälkeen elvytysvalmistetta. Porsaiden vieroitus tehtiin sikalan työrutiinien mukaisesti aina torstaisin ja vieroitusikä oli keskimäärin 28 päivää.

Porsaiden kasvutulokset analysoitiin SAS Enterprise Guide 4.1 -ohjelmistolla. Aineiston analysoimiseksi käytettiin mallia, jossa olivat mukana rodun ja porsimakerran kiinteät vaikutukset ja näiden yhdysvaikutus, ja virheterminä oli karju rodun sisällä. Porsaiden päiväkasvun analysoinnissa käytettiin lisäksi kovariaattina emakon imettämien porsaiden lukumäärää, koska joitakin pahnueita oli tasattu ja koska tasauksia ei tehty kokeen ja roturyhmän sisällä. Analyysissä erotettiin ensimmäinen porsimakerta myöhemmistä porsimakerroista (toinen ja kolmas).

\section{Tulokset ja tulosten tarkastelu}

Kokeeseen tuotettiin yhteensä 81 pahnuetta, joihin syntyi yhteensä 945 porsasta. Näistä vieroitettiin yhteensä 803 porsasta (Taulukko 2).

Keskiarvoja tarkastellen värillisillä roduilla $(\mathrm{DM}, \mathrm{H})$ siemennetyille emakoille syntyi hieman enemmän porsaita (yhteensä ja elävänä) kuin maatiaisroduilla (M, NM) siemennetyille emakoille (Taulukko 2). Aineisto oli kuitenkin niin pieni, että porsaiden lukumäärien tilastollinen vertailu isärotujen välillä ei ollut mielekästä. Värillisten rotujen maatiaisrotuja suurempi pahnuepaino syntyessä näyttäisi olevan yhteydessä syntyneiden porsaiden lukumäärään. Rotujen välinen ero ei kuitenkaan ollut tilastollisesti merkitsevä.

Keskiarvojen perusteella vieroitusvaiheessa NM-porsaita oli vähiten pahnuetta kohti, mutta niiden vieroituspaino oli suurin (Taulukko 2). Tämä heijastui myös pahnuepainoon vieroitettaessa, joka oli suurin NM-porsailla. Porsaiden kuolleisuus M-pahnueissa oli suurin syntyessä, mutta pienin syntymän ja vieroituksen välillä. Tästä ilmeisesti johtui, että vieroitettujen porsaiden lukumäärässä vain NM-pahnueet erottuivat joukosta. Porsaiden kokonaiskuolleisuus syntymän ja vieroituksen välillä oli pienin M-pahnueissa ja suurin DM-pahnueissa. Isärotujen välillä ei ollut tilastollisesti merkitsevää eroa pahnuepainossa vieroitettaessa tai yksittäisten porsaiden vieroituspainossa.

Porsaiden päiväkasvu pahnueaikana oli keskimäärin 283-298 g/pv. H-porsaat kasvoivat hitaimmin ja NM-porsaat nopeimmin. Isärodut eivät eronneet toisistaan tilastollisesti merkitsevästi (Taulukko 2).

Ensikoiden porsaat kasvoivat hitaammin kuin useamman kerran porsineiden emakoiden porsaat ( 279 vs. $303 \mathrm{~g} / \mathrm{pv}$; $\mathrm{p}<0,05$ ), mikä oli odotettu tulos. Rodulla ja porsimakerralla ei ollut yhdysvaikutusta pikkuporsaiden kasvunopeuteen (Taulukko 2). 
Taulukko 2. Eri roturisteytysten porsastuotantotulokset.

\begin{tabular}{|c|c|c|c|c|c|c|c|c|}
\hline Isärotu & $\begin{array}{l}\text { Suomen- } \\
\text { maatiainen }\end{array}$ & $\begin{array}{l}\text { Norjan- } \\
\text { maatiainen }\end{array}$ & $\begin{array}{c}\text { Norjan- } \\
\text { duroc } \times \\
\text { norjan- } \\
\text { maatiainen }\end{array}$ & $\begin{array}{l}\text { Ruotsin- } \\
\text { hampshire }\end{array}$ & SEM & $\mathrm{R}$ & PK & $\mathrm{R} * \mathrm{PK}$ \\
\hline Porsaita kaikkiaan, kpl & 241 & 226 & 244 & 234 & & & & \\
\hline Vieroitettuja porsaita, kpl & 209 & 192 & 201 & 201 & & & & \\
\hline $\begin{array}{l}\text { Porsaita syntynyt, } \\
\mathrm{kpl} / \text { pahnue }\end{array}$ & 11,5 & 11,3 & 12,2 & 11,7 & & & & \\
\hline -elävänä & 10,7 & 10,7 & 11,5 & 10,9 & & & & \\
\hline -kuolleena & 0,8 & 0,7 & 0,7 & 0,8 & & & & \\
\hline $\begin{array}{l}\text { Porsaita vieroitettu, } \\
\mathrm{kpl} / \text { pahnue }\end{array}$ & 10,0 & 9,6 & 10,1 & 10,1 & & & & \\
\hline Kuolleisuus, \% & & & & & & & & \\
\hline - syntyessä & 6,4 & 5,4 & 5,5 & 6,0 & & & & \\
\hline - imetysaikana ${ }^{1}$ & 6,6 & 8,7 & 11,6 & 7,9 & & & & \\
\hline $\begin{array}{l}\text { - syntymästä } \\
\text { vieroitukseen }\end{array}$ & 12,6 & 13,6 & 16,7 & 13,1 & & & & \\
\hline Syntymäpaino, $\mathrm{kg}^{1}$ & 1,81 & 1,87 & 1,81 & 1,90 & 0,07 & ns & $*$ & ns \\
\hline Vieroituspaino, $\mathrm{kg}$ & 10,2 & 10,8 & 9,8 & 10,0 & 0,4 & ns & $*$ & ns \\
\hline Vieroitusikä, pv & 28,8 & 29,4 & 27,9 & 29,0 & & & & \\
\hline Kasvu, g/pv & 293 & 298 & 289 & 283 & 7 & ns & $* * *$ & ns \\
\hline Pahnuepaino, kg & & & & & & & & \\
\hline - Syntyessä & 19,5 & 20,3 & 21,1 & 21,8 & 0,9 & ns & $* *$ & o \\
\hline - Vieroitettaessa & 98,6 & 102,7 & 97,6 & 100,8 & 4,2 & ns & $* *$ & ns \\
\hline
\end{tabular}

${ }^{1}$ Elävänä syntyneistä

$\mathrm{R}$ rotu

PK porsimakerta

\section{Johtopäätökset}

Porsastuotantovaiheessa, kun kotimaisilla maatiais- ja yorkshire-ensikoilla ja -emakoilla tuotettiin kolmiroturisteytysporsaita (isärotu suomenmaatiainen, norjanmaatiainen, norjanduroc $\mathrm{x}$ norjanmaatiainen tai ruotsinhampshire) ei porsaiden painonkehityksessä näyttäisi olevan merkittäviä isärotujen välisiä eroja. Ensikoiden porsaat kasvavat hitaammin kuin useamman kerran porsineiden emakoiden porsaat. Koska aineisto oli tässä tutkimuksessa pieni, porsaiden lukumääriä ja elinvoimaisuutta ei ollut mielekästä testata tilastollisesti. Tutkimuksen tuloksia voidaan siten pitää vain suuntaa-antavina. Tuotannollis-taloudellisesti edullisimman isärotuvaihtoehdon määrittämiseksi on analysoitava porsaiden koko elinkaaren tuotantotulokset.

\section{Kirjallisuus}

Johnson, R. K., Welty, S. D., Venel, R. \& Schooley, J. 1978. A preliminary comparison of the productivity of females of duroc, Yorkshire, landreace and spot breeding. Animal Science Research Report, pp. 117-120 http://www.beefextension.com/research_reports/research_56 94/rr78/rr78 24.pdf, viitattu 8.12.2009.

Muhonen, P. 2004. Pahnuekoolle ja lihaprosentille suurimmat painot. Sika 34 4/2004: 14-16.

Pietola, M. 2002. Duroc-maatiaiskarju työkaveriksi emakkosikalaan. Jokasorkka 9:11

Rauhala, A. 2008. Rahanarvoinen kolmirotuohjelma. Atria Tuottaja 3: 4-5

Serenius, T., Sevon-Aimonen, M-L., Kause, A., Mäntysaari, E.A. \& Mäki-Tanila, A. 2004. Genetic associations of prolificacy with performance, carcass, meat quality, and leg conformation traits in the Finnish Landrace and Large White pig populations. Journal of Animal Science 82: 2301-2306. 